research into the educational problems of developing countries.

\section{Overseas Technical Co-operation}

Is written answers in the House of Commons on July 16, the Secretary for Technical Co-operation, Mr. R. Carr, stated that of the $£ 16$ million provided for Commonwealth education during the five years ending in 1965 , about $£ 2$ million was being made available for the Commonwealth Scholarship scheme, and about $£ 1.7$ million for teachertraining bursaries. Actual expenditure up to March 31 was $£ 867,000$ on scholarships and $£ 814,000$ for bursaries. On the advice of the Committee for University Secondment, he was supplementing existing arrangements by offering a limited number of special awards of $£ 1,500$ a year to outstanding men and women in British universities who were willing to serve for at least two years in selected posts in developing countries of the Common. wealth. These would be additional to the total emoluments ordinarily paid to British university staff in the countries concerned, and the first award would be made in 1964. Overseas universities wero being consulted about the posts that they would like to be filled in this way, and he was confident that the British universities and academic institutions which he was consulting would co-operate fully in the selection and secondment of people of high distinction. Present commitments under Section 1 (3) of the Commonwealth Teachers A.ct, 1960, were expected to result in an expenditure of at least $£ 5$ million, and it was desirable at this stage to maintain the uncommitted balance of $£ 6$ million made available for the quinquennium to meot new requirements which might arise in the next two years. In a written answer in the House of Commons on July 23, the Secretary for Technical Co-operation, stating that he was himself satisfied that Government funds allocated to Voluntary Service Overseas were being effectively used, announced that a target of 500 graduate volunteers had been fixed for 1964 and that the Government had again agreed to meet half the British costs. In addition, Voluntary Service Overseas would send about 300 school-leavers, and the Government would contribute half the cost of this programme instead of a third as this year. The number of volunteers going overseas would thus have risen from about 20 in 1958 to 800 , and the number of graduates from 36 to 500 over three years.

\section{Scientists and Civil Research in Britain}

IN written answers in the House of Commons on July 16, the Parliamentary Secretary for Science stated that 236 British scientists were interviewed by the Joint Board in North America this year, of whom 171 were in the United States, and so far 68 candidates, of whom 51 are working in the United States, had been offered appoint. ments in the United Kingdom. Estimated Government expenditure on civil research in $1963-64$ was $£ 171.447$ million. This included $£ 2 \cdot 841$ million for the Ministry of Agriculture, Fisheries and Food and $£ 1.957$ million for the Department of Agriculture and Fisheries for Scotland, $£ 7.387$ for the Agricultural Research Council, $£ 701,000$ for the Nature Conservancy and $£ 420,000$ for Forestry Commission; $£ 24.8$ million for the Department of Scientific and Industrial Research (including capital and current expenditure on buildings by the Ministry of Public Building and Works), $£ 621,000$ for the Ministry of Power and $£ 445,000$ for the Ministry of Transport; $£ 7.606$ million for medical and health research, including $£ 6.908$ million for the Medical Research Council; $£ 2 \cdot 309$ million for overseas research; $£ 48$ million for the Atomic Energy Authority and $£ 7.87$ million for the National Institute for Research in Nuclear Science; $£ 26.2$ million for universities and $£ 227,000$ for learned societies; $£ 37.778$ million for Ministry of Aviation, $£ 631,000$ to Air Ministry for meteorology, $£ 606,000$ to the Admiralty for observa. tories, oceanography, etc., and $£ 362,000$ to Home Office and Scottish Home Department.

\section{Forestry in Britain}

IN a statement in the House of Commons on July 24, the Minister of Agriculture, Fisheries and Food, Mr. C. Soames, announced that over the decade 1964-73 the Forestry Commission would aim at planting a further 450,000 acres. It would continue to concentrate on acquiring land in the upland areas, particularly in England and Wales, where the population is declining and expansion of forestry can bring considerable social and employment benefits. The Commission would be able to acquire land in other areas where there are good economic reasons, or where planting can maintain or improve the beauty of the landscape. The planting programme for each year, and its distribution between the three countries, would be determined from time to time by the Forestry Minister. In preparing its future programmos, the Commission would bear in mind the need, where possible, to provide public access and recreation, and would direct more attention to increasing the beauty of the landscape. No change was proposed in the strueture of the present grants to private woodland owners. The Government welcomed the increasing acreage of timber planted by private owners, and the tradition of skill and knowledge and the research which had been carried out in private forests had been of great benefit to the nation. This steady expansion in both public and private forestry meant that a growing volume of home-produced timber will be coming on to the market which would benefit Britain's balance of payments already of about $\$ 14$ million a year. Clearly, it would become more necessary to direct greater attention to the whole problem of the marketing and use of homegrown timber. In answer to questions, Mr. Soames said that with planting by private owners, some 80,000 acres a year would be planted for the next five years and the Commission would, in particular, consult the National Parks Commission in respect of amenity and the beauty of the landscape, employing a landscape architect to assist. Mr. Soames also agreed that the closest co-operation between farming and forestry interests was essential.

Department of Scientific and Industrial Research and NATO Studentships

IN a written answer in the House of Commons on July 19, the Parliamentary Secretary for Science, Mr. D Freeth, gave the number of students holding Department of Scientific and Industrial Research studentships (including NATO studentships) at November 1, 1962, as 3,473 , of whom 3,412 held their studentships at universities and colleges in Great Britain and 2 in Northern Ireland. They represented 38.5 per cent of full-time postgraduates in their fields in these institutions. Of 991 such students who enterod employment on the termination of their awards in the year ended September $30,1962,357$ joined the staffs of home universities $(20 \mathrm{l}$ in teaching and 153 in research posts) and 18 the staffs of colleges of advanced technology. In addition to these 991 students, 141 were continuing thoir postgraduate training and 48 had taken research fellowships from the Department or NATO. A further 165 students joined the staffs of overseas universities, 97 for teaching posts and 68 for research.

\section{A Blood Typing Service for Cattle}

Following discussions with organizations interested in cattle breeding, the Agricultural Research Council is to set up a blood typing service for cattle at its Animal Breeding Research Organization in Edinburgh. The objectives of such a service, which will be available to cattle breeders on a fee basis, are, from the point of view of the farmer, to obtain a doscription of the blood characteristics of a cattle beast which can be used to determine its relationship to another animal for which similar 